\title{
Viera y Clavijo, poeta ilustrado
}

\author{
SEBASTIÁN dE LA NUEZ \\ Universidad de La Laguna
}

La poesía de don José de Viera y Clavijo hay que entenderla desde los signos culturales e históricos de su época, no desde el barroco, no desde la escolástica, sino desde el neoclasicismo y la ilustración. Esto es, desde sus corrientes tradicionales y enciclopedistas, que se agitaban en el mundo de las ideas, no sólo literarias sino políticas y científicas, a lo largo del siglo XVIII, en el seno de la sociedad y desde el momento histórico que le tocó vivir a Viera en Canarias, en España y en Europa. Todo ello será mucho mejor comprendido si se tiene en cuenta lo que dice Guillermo Carnero en su excelente libro La cara oscura del siglo de las luces ${ }^{1}$, por lo cual «hoy vemos al siglo XVIII como una dualidad dialéctica, cuyos polos son, por una parte, la razón normativa y por otra la emoción y sensibilidad», de la que participa la extensa obra poética de Viera, cuya vida abarca lo suficiente para englobar desde las últimas tendencias de la poesía barroquizante y de las teorías y temas de

1 Ediciones de la Fundación J. March y Ed. Cátedra, Madrid, 1983, p. 14. 
la poesía didáctica y raciocinante, cientifiscista y filosófica, hasta las últimas tendencias del neoclacisismo apasionado y la nueva sensibilidad que preludia el prerromanticismo.

Para Agustín Espinosa ${ }^{2}$ «el siglo XVIII español es un fenómeno patológico», «un siglo enfermizo que no se atreve a vivir de sus propias fuerzas». Y eso que, como es sabido, nuestro escritor realizó sus estudios de investigación en torno a la gran figura de su paisano en el contorno vital e histórico de su época. Añade más adelante: «el clasicismo del siglo XVIII es un clasicismo de segunda mano, por incapacidad de remontarse hasta la fuente original». Partiendo de estas premisas, desde este signo, no es extraño que cuando Espinosa hace la valoración de las dos vertientes de la obra de Viera y Clavijo, si por un lado acierta plenamente cuando sitúa a Viera junto a Feijoo, «anunciador -como dice- de su caudal signo, y con la Enciclopedia, maestra de su primer deletrear» (Gaceta de Daute, Vida literaria, Historia de Canarias, Diccionario de Historia Natural), por otro se deja llevar, arrastrado por la sensibilidad poética de su tiempo, a una posición radical al juzgar el aspecto creativo de su obra en verso, que es, a su parecer, «mediocre, átona, infortunada, extraña a toda poética esencia, vacía de imaginismo, hambrienta de corazón», cargando su verdadero sentido y estilo poéticos no a sus versos, sino a su prosa, a la de la Historia de Canarias, «donde están — como él escribe, sin faltarle razón- los mejores primores», donde «han de buscarse siempre las hadas que nos lleven al cielo ignorado, inédito, acaso, para el mismo Viera...».

No se trata, pues, aquí de delimitar y juzgar con criterios estéticos permanentes la obra poética de Viera -y podemos estar de acuerdo con casi todos los calificativos que le aplica Espinosa, sin examinarla mucho-; lo que pretendemos simplemente es ser más justos con esa parte de la producción de nuestro polígrafo ilustrado juzgándola desde su perspectiva abarcadora y tolerante, tratando de comprender el porqué de ese "prosaísmo», esa pretendida falta de imaginación, que aparentemente nos lleva a juzgarla sin sentimiento y sin rasgos mínimamente poéticos, en el sentido que se ha considerado la poesía desde el romanticisco para acá, como expresión de los sentimientos íntimos, es decir, reduciéndola a la poesía lírica, supervarolándola hasta el punto que se ha querido identificarla con el fenómeno exclusivamente literario, excluyendo otras muchas formas de expresión y de contenido que también pertenecen a la historia literaria.

2 Véase Sobre el signo de Viera, ed. Instituto de Estudios Canarios, Universidad de La Laguna, 1935. 
Ya hace unos cuantos años que nuestros críticos y pensadores, así como los hispanistas de allende nuestras fronteras, están tratando de revalorizar la época neoclásica, o al menos justificar un nuevo enfoque de la producción literaria de nuestro siglo XVIII. Julián Marías atribuye la falta de estimación por las manifestaciones literarias de ese siglo al haber estado condicionada la crítica a los géneros literarios tradicionales preferidos: «la poesía, la ascética, la mística, la novela y la literatura dramática han sido objeto de valoración superior», pero no son éstos los géneros donde se encuentra lo más interesante del setecientos, dice, refiriéndose al ensayo, a la crítica, a la investigación que «representa una innovación que fue muy fecunda y pudo haberlo sido mucho más ${ }^{3}$. Y es que la poesía tenía mucho de ensayo, de crítica y hasta de comunicación social, filosófica o científica, por lo menos en el gran período neoclásico que va desde 1770 a 1820 . La poesía así concebida quedaba aún como un terreno maldito, un jardín prohibido, en el que no se podía entrar sin destrozar sus parterres bien trazados, las pérgolas de sus pensiles versallescos, hasta que Russell P. Sebold, en 1970, en un conjunto de ensayos titulado El rapto de la mente ${ }^{4}$ (título tomado de una frase de Feijoo, que intenta decirnos que «el furor es el alma de la poesía») desmontó uno a uno todos los mitos antineoclásicos que impedían penetrar en el bello y bien medido jardín de la poesía, trazado a cordel y cruzado por invernaderos, donde se cultivaban las más exóticas flores todavía no bien adaptadas a nuestro clima exuberante y barroco, que trataba a estas plantas literarias descuidadamente, tachándolas de antinacionales y prosaicas, motejándolas de seudoclásicas, injertos a la francesa o a la italiana.

Sebold nos demuestra, en su ensayo «Contra los mitos antineoclásicos españoles», que los poetas de nuestro siglo XVIII siguen, en gran parte, la tradición nacional, imitando a Garcilaso, Fray Luis de León, Villegas, Quevedo y hasta ciertas imágenes de Góngora, como veremos en algunos pasajes de los poemas de Viera; que cuando siguen las reglas poéticas y dramáticas están siguiendo directamente a Aristóteles, quien recomienda «la perfección del estilo que sea claro y no bajo», a Horacio cuando quiere que se hagan «diez correcciones / después de muchos días de borrones», como se dice en la traducción de la célebre Epístola realizada por nuestro Iriarte, cosa que corresponde con las exigencias de los mejores poetas contemporáneos de la poesía europea en la płimera mitad de nuestro siglo (Mallarmé, Valéry, Juan Ramón, Gui-

3 Véase La España posible en tiempos de Carlos III, Madrid, 1973, p. 19.

4 Ed. Prensa Española, Madrid, 1970. 
llén, etc.); por otra parte, Ignacio de Luzán, nuestro preceptista, que se inspira más en los clásicos que en los modernos, como ha demostrado el mismo crítico, recomienda, igualmente, que el poeta debe «templar el fuego del ingenio en sus reflexiones», o Alberto Lista, el maestro neoclásico de los románticos, afirma que «hay cierta lógica que yo llamo lógica de la poesía», y sus leyes son tan severas y necesarias como la lógica vulgar, y, finalmente, un autor anónimo francés descubierto por José Luis Cano, «asevera que desterradas las fábulas y desterrada la magia, hubiera sido imposible ser poeta, si no se hubiese sustituido a ellas la filosofía y el arte de pensar». Y añade a continuación: «El arte del poeta debe ser el hacer de las verdades filosóficas otros tantos cuadros, el hacerlas del resorte de la imaginación», y que para captar, en la poesía, el sentido auténtico de la vida de la que el siglo XVIII está animado hay que comprender los fundamentos del siglo filosófico. Así comprenderemos no sólo la obra histórica, científica y literaria de Viera, sino también su poesía.

En resumen, Russell $P$. Sebold quiere decirnos que la verdadera creación poética neoclásica nace, como todas, de la inspiración, de la imaginación, del espíritu; pero, en el siglo de las luces, al desaparecer las fuentes de la inspiración mágica, de los poderes ocultos o de las firmes creencias religiosas, en suma, al cambiar el mismo sentido de la concepción de la vida, la nueva poesía tiene que partir de una «ratio mentis», de una razón mental, que necesariamente producirá una poesía racionalista o lógica que se somete de buena gana a las leyes, a unas leyes que emanan de una tradición clásica, de una larga experiencia de las formas poéticas, las cuales tienen su última razón de ser no en un «quid divino», sino en la propia naturaleza, que nos suministra sus eternos modelos de belleza y de verdad, pues no de otro modo pensaron y crearon los poetas clásicos y los del renacimiento europeo.

Pero, aun así, hay que mantener la ponderada opinión de nuestro estudioso de la poesía del XVIII, Joaquín Arce, quien dice que «no hay que caer en el extremo opuesto, intentando una revalorización de lo que debe quedar tan sólo justificado y admitido en un sentido funcional, sin llegar a improcedentes restauraciones de un material sólo interpretable desde las distintas perspectivas de un momento ${ }^{5}$.

5 Véase La poesía del siglo ilustrado, Ed. Alhambra, Madrid, 1980, p. 31. 


\section{Etapas vitales y poéticas de Viera}

La vida y la obra de Viera y Clavijo son tan amplias que abarcan todo el siglo de las luces (que, como es sabido, no coincide plenamente con el comienzo ni con el fin del siglo XVIII), todo el llamado siglo ilustrado desde sus primeras manifestaciones hasta prácticamente su extinción cultural e histórico-literaria, aunque sus derivaciones sobrevivieran algunos años más después de su muerte en 1813 , como lo prueban los nombres de Quintana, de Lista, de Gallego, etc., pues hay que convenir que las tendencias prerrománticas se dan simultáneamente a las neoclásicas y éstas incluso perduran dentro del pleno romanticismo.

Para comprender mejor la trayectoria vital y poética de Viera, y al mismo tiempo poder estudiar esta simbiosis de vida y poesía, desde la perspectiva de la época, es conveniente seguir las cuatro etapas de la vida de Viera establecidas generalmente por sus biógrafos.

La primera etapa, correspondiente a la mocedad de José de Viera, transcurre en la Orotava y en su Puerto, y se la puede definir como época de aprendizaje (1731-1756), en la que nuestro futuro ilustrado estudia Humanidades y aprende a versificar. Ahora es cuando se pone en contacto con las obras francesas de los enciclopedistas que entraban clandestinamente por el Puerto de la Cruz, leyendo, al mismo tiempo, la obra del fraile racionalista Jerónimo Benito Feijoo, cuya lectura, como él mismo confiesa, fue. «como una ráfaga de feliz claridad» en medio «de la lóbrega noche» de la escolástica.

Después de haber tomado las órdenes sacerdotales mayores en Las Palmas, en 1754, comienza la segunda etapa de su vida al trasladarse a La Laguna en 1757, y donde asiste - como ya se ha estudiado- a la tertulia de Nava Grimón, en la que pronto llegó a ser, a pesar de su juventud, el indiscutible animador, tanto por su ingenio como por sus conocimientos generales. A esta etapa de su vida pertenecen las composiciones festivas y satíricas, que reciben, por un lado, las influencias de los poemas y relatos del ya viejo Marqués de Villanueva del Prado, asiduo tertuliano, $y$, por otro lado, las influencias de las producciones en verso de don Diego de Torres Villarroel y de Quevedo, que se manifiestan en la obra, en prosa y verso, de El piscator lacunense, entre las que pueden encontrarse los poemas relacionados con la sociedad lagunera del siglo de las luces, como «Títulos de comedias españolas adaptadas al carácter de cada dama y caballero de La Laguna», o la "Chulada burlesca a la intemperie de La Laguna», etc. Don Enrique Romeu, en 
su documentado estudio sobre la Tertulia de $\mathrm{Nava}^{6}$, hace una detallada exposición de este momento en la vida del ilustrado sacerdote, con varias alusiones a sus versos festivos, satíricos y burlescos, que nos eximen de entrar en mayores profundidades eruditas. Recordaremos, sin embargo, el ingenio de Viera y Clavijo, que, en esta época y circunstancias, se manifiesta en dos vertientes: una burlesca-histórica y otra festivo-irónica, sin reparar en que en ambos tipos de composiciones hubiera ciertos matices irreverentes para los libros sagrados, sea el Génesis o el Nuevo Testamento, que pudieran hacerle sospechoso de influencias volterianas o enciclopedistas a los celosos familiares del Santo Oficio. Véanse, entre las primeras, estas dos quintillas:

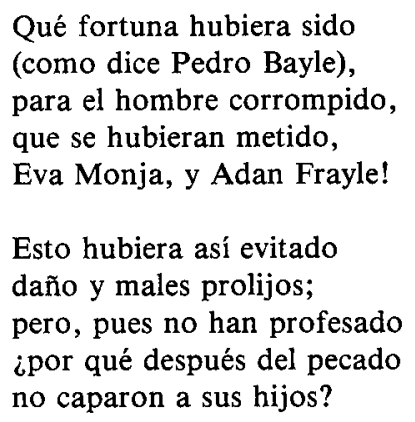

Otra composición, donde se mezclan ternura, gracia y también algo de irreverente ironía, con alusiones a los acontecimientos de la época, es la composición hecha por Viera, para el día de Navidad, para ser representada por Alonsito, Catalinita y Antonia María, hijos de algunos próceres de la tertulia de Nava. He aquí cómo nos presenta el momento de la adoración de los Reyes:

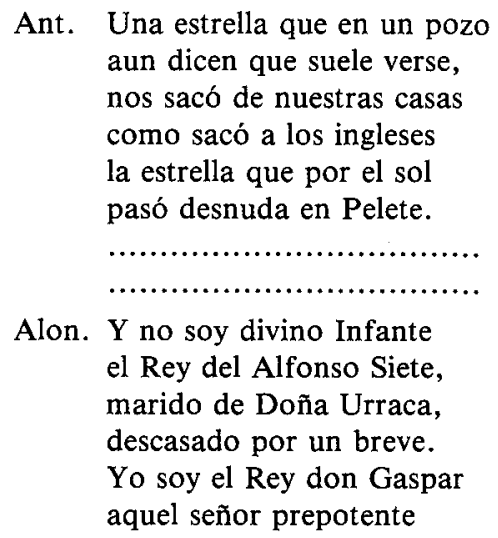

6 Ed. Ayuntamiento de San Cristóbal de La Laguna, 1977. 


que allá en las islas Molucas
bebe el caldo con especies.
Cath. Ni a mí tampoco me Ilaman
Doña Catalina Ocene
porque con el Obispo de Sota
del Rey hago papeles,
y me nombro Balthazar
en Babilonia y en Telde.

También contribuye Viera en esta época - como bien apunta el Conde de Barbate en la citada obra - a la sátira burlesca contra la oratoria retórica y barroquizante, como la iniciada por el Padre Isla en su relato biográfico-burlesco de Fray Gerundio de Campazas, del que escribe una continuación el propio Viera. Pero recordemos aquí un soneto que compone en «elogio al nuevo método de predicación abrazado por la mayor parte de los oradores de la Octava de Nuestra Señora de los Remedios» (hoy catedral), año de 1767, que dice:

\footnotetext{
¡Oh pura; ¡Oh celestial! ;Oh verdad santa! que en tu cátedra y trono perseguida de una oratoria loca y atrevida sufriste tanto insulto, injuria tanta.

Vuelve de tu destierro... canta, canta, el triunfo de la victoria merecida, ya la cláusula muere, ya en huida el falso asunto está. Ya no se aguanta y el vil realce y profano texto, ya se dejan los vanos calamistros, y vestida de un traje más modesto sin temer de la crítica registros puede decir a vista de todo esto:

Hoy conozco en sus obras, mis ministros.
}

Es revelador y sintomático el contenido de este soneto que proclama y aboga por una oratoria más sencilla, como se estaba abogando, en esta época, por una poesía y una prosa más simple, pues, como dice Viera, se presenta ya «vestida de un traje más modesto», rechazando las cláusulas complicadas y «el falso asunto», tan propio de la literatura y la retórica barrocas, para implantar los asuntos positivos y útiles basados en la lógica práctica de la razón y el sentimiento de la nueva época.

Finalmente, también pertenecen a este momento otros poemas de tono más solemne y filosófico, como el panegírico elegíaco dedicado a la muerte del célebre personaje, también poeta, el citado Vizconde de Buen Paso, don Cristobal del Hoyo y Solórzano (1677-1762), y en donde se notan claras reminiscencias de nuestros poetas del Siglo de 
Oro, especialmente del Quevedo poeta ascético, como se ve desde el comienzo:

\author{
En fin, en esta Iglesia, en este Hoyo, \\ sin lápida, sin mármol ni epitafio, \\ sin ofrenda, sin tumba y sin escudo \\ Don Cristobal del Hoyo halló el descanso.
}

Obsérvese el juego de palabras entre el «hoyo» donde yace y el apellido del prócer, los versos formados por elementos trimembres o bimembres, en figura de polisíndeton: «Sin lápida, sin mármol, ni epitafio». Significativa es la estrofa (formada por endecasílabos asonantes al estilo de los romances heroicos) que expresa el carácter de crítica ilustrada cuando Viera sella su enemistad con la mentira y las supersticiones, dentro de la más estricta línea feijoniana; no en vano desde 1759 reinaba Carlos III, el Rey ilustrado:

Perdió los embustes su enemigo,

los hechizos y brujas su contrario.

Termina el poema con todo el peso de la sabiduría senequista y clasicista pasada por el tamiz del pensamiento del autor de los Sueños:
¡En ochenta y cinco años qué vería!
pero como este tiempo es momentáneo,
él murió confesando que a su vida
un puro sueño de poco rato.
Encomendarlo a Dios, tú, pasajero,
que al sepulcro también vas caminando,
y sabes que vivir ocho u ochenta
lo mismo viene a ser tarde o temprano.

No es casual que la tercera etapa de la vida y la obra de Viera y Clavijo comience con su traslado a la Península en 1770, para iniciar la publicación de sus Noticias históricas de Canarias, y que este momento coincida con el apogeo de la generación de los ilustrados españoles en pleno reinado de Carlos III, en los que figuran los conocidos nombres del Padre Andrés, José Cadalso, Jovellanos, Fernández de Moratín (padre) y otros. Esta etapa se considera como el comienzo de la época propiamente ilustrada del neoclasicismo. Sin duda Viera, para captarse la simpatía de la corte y de sus protectores, compondría poemas panegíricos al Marqués de Santa Cruz, al Marqués de Aguilar y a otros personajes de la nobleza española, en los que se incluye un poema dedicado a «Las cuatro jornadas anuales de Carlos III». Por otra parte, los viajes de Viera por Europa, 1776-78 y 1779-81, no sólo ampliaron el panorama de los conocimientos de nuestro polígrafo en su aspecto científico, con su contacto con Voltaire y Benjamín Franklin y las visitas a los museos de Historia Natural, así como los experimentos de quí- 
mica y física que ampliaban los llevados a cabo en Madrid en el laboratorio del Marqués de Santa Cruz, sino que cambiaron, en cierto modo, el panorama de su quehacer poético, creando una poesía más didáctica, y por lo tanto más prosaica y objetivista, donde se persigue más la precisión informativa que la retórica imaginativa, aunque, con todo, ésta no está ausente ni siquiera en su famoso y científico poema de Los aires fixos (1779-84) ${ }^{7}$ y también el canto a El globo aerostático. Así, bajo la forma métrica de la octava real propia de la poesía épica, compone todo su poema a los llamados «aires fijos», cuya estrofa tercera dice:

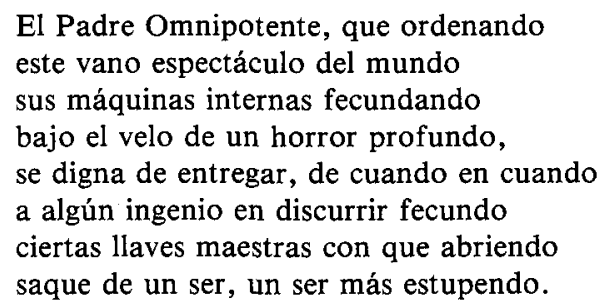

Hay que tener en cuenta que el tema de la ciencia, una vez desaparecidos los grandes motivos caballerescos y los descubrimientos de los hombres, sean históricos o míticos, era la gran aventura digna de ser cantada. Así, en vez de una Cristiada, un Paraíso perdido, unas Lusiadas (aunque todavía quedaron, como prolongaciones renacentistas, poemas como la Henriada volteriana, traducida por Viera, o las Hazañas de Cortés, del mismo autor canario), era mucho más importante el tema del descubrimiento del hidrógeno, el oxígeno, el anhídrido carbónico, o las «Bodas de las plantas», todos cantados por nuestro poeta ilustrado, aunque con las mismas formas e imágenes con que antes se cantaba a los héroes de las Cruzadas o a los conquistadores de América, como lo habían hecho Tasso o Ercilla, mezclando realidad y mito. Así, en el canto VI del poema citado, dedicado a la «máquina aerostática», hay una perfecta conjunción entre lo científico y lo simbólicomitológico:

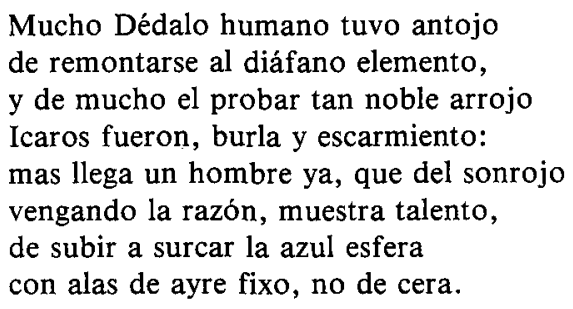

Mucho Dédalo humano tuvo antojo de remontarse al diáfano elemento, y de mucho el probar tan noble arrojo Icaros fueron, burla y escarmiento: mas llega un hombre ya, que del sonrojo vengando la razón, muestra talento, de subir a surcar la azul esfera con alas de ayre fixo, no de cera.

7 Véase ed. con Prólogo del Dr. Luis y Yagüe, Las Palmas, 1876. 
Claramente se refleja aquí el triunfo de la razón sobre el mito, el hombre racional, frente al héroe mitológico. He aquí la referencia al hombre concreto, que fue

$$
\begin{aligned}
& \text { soberbio si de subyugar la altura } \\
& \text { y en carro frágil semi-dios triunfante, } \\
& \text { sin brújula, timón, remo, ni antena } \\
& \text { pisar las torres y pasar el Sena. }
\end{aligned}
$$

Sorprendente es encontrar en este poema de Viera, reputado como uno de los más prosaicos y antipoéticos —desde la perspectiva romántica- unas metáforas de clara estirpe gongorina, tanto en la utilización de los sintagmas como en la estructura, pues en vez de decirnos sencillamente que los pasajeros del globo ascienden a las nubes mientras las aves de los corrales se asustan, utiliza la siguientes cláusulas:

\footnotetext{
Mientras así nuestros viajeros andan, y el largo campo desde el cielo notan, las palomas de Venus se desmandan, los pavones de Juno se alborotan.
}

Señala Carnero que «el concepto de verosimilitud tiene lejana justificación en la Poética de Aristóteles», entre las que el crítico llama «enigmáticas declaraciones» (que a la luz de la poesía de Viera no lo resultan tanto): «que se debe preferir lo imposible verosímil» a «lo posible inverosímil» o que «no corresponde al poeta decir lo que ha sucedido, sino lo que podría suceder, es decir, lo posible según la verosimilitud o la necesidad» ${ }^{8}$, lo que se cumple plenamente en una de las últimas octavas al globo aerostático. El poder de la lógica puede llevarnos a adivinaciones futuribles, porque en este poema hay un momento en que Viera se convierte en un poeta-profeta, no en el sentido de los románticos, por pura exaltación de la mente calenturienta y el espíritu arrebatado, sino por el simple raciocinio del intelecto, como nos muestra en una de las últimas octavas dedicadas al globo aerostático, en la que llega a pensar nada menos que en "navegar hasta la luna» y compara a tal aventurero con un futuro Colón, como, luego, tantas veces, han proclamado nuestros periodistas y poetas de hoy después de que la premonición se ha hecho realidad, justamente 190 años más tarde. He aquí la octava profética:

Bien podrá ser que un día la Fortuna haga nacer otro Colón segundo que emprenda navegar hasta la Luna como aquel hizo viaje al nuevo mundo

8 Véase op. cit., p. 20. 
que un Herschel lince, sobre tal columna, nuevos planetas halle en el profundo; y que algún Fontenelle tanto viva que ande los astros y su Historia escriba.

Poco antes de volver de su último viaje por Europa, en Viena, tiene la humorada, como un nuevo Villon o un Quevedo, de hacer un testamento poético en forma de soneto, donde deja una parva herencia a su amigo don Isidoro Bosate, secretario del Excmo. Sr. Conde de Aguilar, embajador de España en la corte de Viena, y en sucesivas enumeraciones de modestos objetos, muchos de ellos ya desconocidos para nosotros, pero característicos del ajuar de un eclesiástico pobre e ilustrado, forma su composición del siguiente modo:

\footnotetext{
Una manta de lana, una calota, un sombrero candil, que pie de paja, un bote de bornada, y una caxa que tuvo polvos de bergamota: una chupa sin mangas algo rota, una caxilla retorcida y maja, un frasquito con opio, rica alhaja, cuatro billetes, y una gran pelota.

Dos trozos de rabat, palos de dientes, una toma de sal de Inglaterra, tres petrificaciones excelentes, dos zapatos de cuero de becerra, dos alzacuellos viejos, indecentes, una bayeta, un libro y mucha tierra.
}

El mismo poeta nos dejó, al margen de su manuscrito, anotaciones explicativas de algunos de estos términos acaso poco conocidos ya para su tiempo. Veamos: una calota era «un solideo francés de cuero», es decir, un casquete eclesiástico para cubrirse la corona; «un bote de bornada» o de codeso; "polvos de bergamota» era un tabaco en polvo aromatizado con esencia de ese fruto; «la chupa» era, como se sabe, una pieza masculina que cubría el tronco, con cuatro falditas de la cintura abajo y con mangas apuntadas; el rabat, anota el poeta, es un cuello eclesiástico francés; la «sal de Inglaterra» es un compuesto químico de carbonato de amonio, que por ser de olor fuerte y penetrante lo llevaban las señoras en un frasquito para reanimar a las desvanecidas, y las «petrificaciones excelentes» son el resultado de la mineralización de vegetales o animales lograda por medios naturales o en el laboratorio, para el estudio o el recreo. No resistimos la tentación de recurrir a estos indicios, caídos al azar en este testamento poético-prosaico, para esbozar la figura de Viera en las cortes europeas en el setecientos, como un «abate joven de los madrigales», vistiendo una chupa cortesana a me- 
dio uso, su sombrero candil de tres picos, o su eclesial bonete de cuero - como le vemos en su más conocido grabado-, expeliendo, de vez en cuando, polvos de bergamota, y un alzacuellos a la francesa, calzado con elegantes zapatos, ya un poco estropeados por tanto viaje, de cuero de becerra; con un palillo de dientes en la boca, después de una frugal comida, y guardados en la faltriquera el opio y las sales, por si en «la noche de fiesta, y el baile de trajes ostentando» su gloria de triunfos mundanos, «la divina Eulalia, vestida de encajes», después de bailar «galantes pavanas, fugaces gavotas», pudiera desmayarse de tanto reír y reír «al oír las quejas de sus caballeros». Mas el cuadro no es tan frívolo; este abate, además de hombre de mundo y sonrisa volteriana, es un ilustrado y estudia la naturaleza en las petrificaciones de vegetales o animales en los gabinetes de Viena o de París, donde hay muchos libros; acaso uno prestado o comprado sea de ciencias, de filosofía, de literatura, y, por qué no, un breviario de oraciones o las sentencias galantes del Conde de la Rochefoucauld.

Aunque el largo poema de Los Meses (dividido en cuatro partes dedicadas a cada una de las estaciones y en doce cantos a los meses correspondientes) está concebido en París entre 1778 y 84, al oír celebrar la lectura del escritor francés Rucher, fue compuesto seguramente a su vuelta de Francia, en Madrid, y publicado en Canarias. El mismo Viera nos dirá, en el prólogo, que «es poquísimo lo que fuera del plan y de uno y de otro pensamiento debo a la mencionada obra de Rucher». Reconoce, sin embargo, su osadía al acometer el tema porque lo que «no era posible en lo que parecía tener en Francia poco mérito, llegase a conseguirlo en los países españoles»; tal era el ascendiente que la literatura francesa gozaba entre la élite de los críticos y escritores ilustrados en España, y mucho menos era esto posible «cuando en aquella composición se tocaban algunas materias ajenas a nuestro gusto, costumbres, ideas y modo de pensar». Mas Viera opinaba que el tema de las «vicisitudes de la naturaleza a influjo de los varios aspectos del sol y de la tierra durante el período de un año, son propios para encender el astro poético». Concurrían, pues, en el tema de las estaciones del año varios elementos del pleno neoclasicismo: a) tema prestigiado por un autor francés; b) la exposición de los cambios de la naturaleza, es decir, un poema científico didáctico, y c) tema del sentimiento bucólico dentro de un ambiente real y verdadero. Todos estos elementos los vemos en el poema que encabeza esta obra, escrito en romance heroico (cosa que se mantendrá en toda la composición) y que contiene una invocación a Apolo, padre de las musas y de Hércules: visión de la naturaleza en paz que, contemplada por el poeta según el modelo de Fray Luis de 
León, nos envuelve en un ambiente idealizado, bucólico, pero al mismo tiempo real.

Para nosotros, Los Meses representa la plenitud expresiva de Viera, desde el punto de vista del neoclasicismo propiamente dicho en su variante isleña y del sentimiento del paisaje, como se puede observar en dos pasajes: uno dedicado al Teide y otro a la Selva de Doramas. En el canto cuarto, dedicado al Estío, en las estrofas correspondientes al mes de Junio, nos encontramos con ese emocionado recuerdo de una ascensión al Teide, al que llama «Pico gigante» que «animoso / entró con los Titanes en la guerra». Pero veamos cómo, en su exposición descriptivonarrativa, nos va mostrando, en un alarde de soltura versificatoria y de poesía que podríamos denominar idílico-realista, los distintos estadios de la gradual subida al monte colosal:

Ya dejo atrás aquella hermosa cueva, habitación de hielo: ya me encumbro sobre el borde exterior de su caldera, cuando la noche, a quien persigue el alba, lleva en su negro manto las estrellas, y apenas con las rosas de sus manos la Aurora en el Oriente abre las puertas, ya las florestas, montes, pueblos, valles, se me van descubriendo, y me ordenan así como se vieron $y$ ordenaron cuando tuvieron ser la vez primera. El teatro se ensancha: el mar cerúleo un inmenso horizonte me presenta, donde las demás islas se divisan entre una roja y mal dorada niebla.

El otro paisaje canario es el dedicado a la Selva de Doramas, en Gran Canaria, en el que evoca al poeta Cairasco, cantor de ese famoso bosque, y protesta por su destrucción; destacándose aquí sus elementos sentimentales y nostálgicos en la descripción de la Naturaleza:

Sitios queridos de las nueve musas en cuyos frondosísimos andenes paseó de su numen agitado el divino Cairasco tantas veces. ¡Montaña de Doramas deliciosa! ¿Quién robó la espesura de tus sienes? ¿Qué hiciste de tu noble barbusano? Tu palo blanco ¿qué gusano aleve le consumió? Yo vi el honor y gloria de tus tilos caer sobre tus fuentes...

Obsérvese al naturalista que enumera las extintas especies del arbolado canario, y continúa citando a los pájaros $y$, en una imagen bu- 
cólica, a los zagales y pastores, que ya no podrán grabar sus nombres en «corteza dura o plana suficiente»; pero también al ecólogo, que se preocupa por la esperada resurrección del monte cuando añade en su poema estos versos:

Huid, huid: sacad de esta montaña las manadas de cabras y los bueyes que devoran los brotes cuando nacen, y no permiten que nacidos medren.

La poesía ligera, la anacreóntica típica del neoclasicismo sensible, tuvo también en Viera su cultivador, como correspondía a un buen abate culto, cortesano, galante. Así tenemos poemas como el «Idilio pastoril»:

\footnotetext{
Ayer en la pradera

mi perro te hizo halagos,

y al punto le corriste

levantando el cayado;

mas si el perro de Tirso

sigue tal vez tus pasos, lo llamas por su nombre.

¡Ah! yo no soy amado.
}

En una obra titulada Fruta verde del Parnaso, Viera reunió una colección de poesías líricas: anacreónticas, paisajísticas, bucólicas, etc., que junto a las «Anacreónticas» del «Festín de las Vistillas de Madrid», "La Mujer» $\mathrm{y}$ «A una tórtola», nos muestran cumplidamente la cuerda lírica que no falta en ningún poeta neoclásico (Cadalso, Iriarte, Meléndez Valdés, etc.), y que se completa con la evocación del mundo clásico y renacentista de la «Egloga genetliaca». Para completar el lado «oscuro del siglo de las luces», tenemos el poema dedicado al «Sentimiento», formado por cuarenta y tres estrofillas heptasilábicas en romancillo, y que comienza:

Canto del Sentimiento

los dulces incentivos,

las felices ternuras, los amables deliquios.

Oh tú gloria del sexo

la sola en quien registro con frente de Minerva, el pecho de Calipso.

La cuarta y última etapa de la vida de Viera transcurre en Gran Canaria, adonde fue, en 1784, a hacerse cargo de su plaza de arcediano de Fuerteventura en la catedral de Las Palmas, y donde permanecerá hasta su muerte, acaecida en 1813. Ahora, en esa especie de destierro 
gustoso, tendrá mucho tiempo para dedicarse a sus ocupaciones favoritas, a hacer experimentos químicos y físicos, investigaciones de Historia Natural, traducciones y adaptaciones de obras dramáticas, etc. Entre estas últimas tradujo del francés: El conde Warwich, de la Harpe, en 1795; Mustafá, de Chamfort, en 1800; Berenice, de Racine, en 1812, y del italiano, Merope, de Maffei, en 1801. También tradujo del latín canciones y oraciones de carácter religioso, como el «Dies irae», el «Ave Maris stella», el «Magnificat», o bien los ritos eclesiásticos del año litúrgico, como «A la festividad de San José», «Los responsorios de la Navidad y Epifanía». Dentro de esta dedicación religioso-ascética relacionada con su actividad eclesiástica, leyendo el libro del Eclesiástico, debieron de llamarle la atención las citas referentes a la Botánica, pues coincidía esta época con su dedicación, por largo tiempo, a la confección del Diccionario de Historia Natural de Canarias. De esta doble devoción religioso-profana o eclesiástico-científica, junto con su adoración por la Virgen, debieron de surgir las dos octavas reales, que tenían como base sendos versículos (18 y 19) del capítulo XXIV del Libro del Eclesiástico, dedicado a la alabanza de la Sabiduría, que, como se sabe, se identifica con la Virgen. El versículo 18 dice completo:

Quasi palma exalta sum in Cades, et quasi plantatio rosae in Jericho.

Se refiere, como es sabido, al lugar y la fuente de Cades, arrasados a causa de la murmuación de los israelitas y por no haber glorificado Moisés a Jehová ante el pueblo. Veamos cómo Viera sabe ensamblar la alegoría botánica y el suelo geográfico, bíblico y canario donde crece la palmera de la primera parte de la octava con la segunda parte, de tema religioso-mariano:
Gallarda por su aspecto se levanta
la palma, que a los cielos se avecina, tanto que ya en Cades no existe planta que llegue a su estatura peregrina:
A todo lo criado, oh Virgen santa, te aventajas con prole tan divina, siendo tu dignidad, de un raro modo, sólo menor que Dios, mayor que todo.

Pero sus composiciones originales de esta época - como las de las anteriores - son casi todas de carácter profano. Entre éstas se encuentra un grupo de poemas épico-históricos como El segundo Agatocles, Cortés de Nueva España, escrito en octavas, y La rendición de Grana$d a$, escrito en romance endecasílabo; y un canto dedicado a un importante hecho heroico protagonizado por sus contemporáneos de Tenerife, la oda «A la victoria conseguida por las armas de la isla de Tenerife 
mandadas por don Antonio Gutiérrez, teniente general de los ejércitos, contra la escuadra inglesa del Contra-almirante Horacio Nelson» (1797), escrita en sextinas aliradas, vibrantes de orgullo patrio. Viera, como un poeta clásico, se dirige a la musa de la Historia diciéndole:

\author{
Pondera las derrotas \\ del orgulloso Inglés, que si domina \\ Mares, Puertos, Flotas; \\ ya encuentra deshonor, verguenza y ruina, \\ cuando audaz amenaza \\ de Santa Cruz la afortunada plaza.
}

A veces logra algunas estrofas no exentas de cierta expresión épica y sonora como la siguiente:

Se extiende la contienda

en la Caleta, el Muelle y el Barranco:

vuela la Muerte horrenda

al tiroteo por el frente y flanco;

y el Aire, confundido,

es nube, es resplandor, es estampido.

Aunque el poema, en su conjunto, no sea de los más acertados de Viera, hay también alguna estrofa que denota cierta ternura y sentimiento, como la dedicada al epitafio que abarca a tinerfeños y franceses caídos en el combate:

Descansad en el seno
de la paz y del gozo merecido,
todo corazón bueno
de vuestro epitafio enternecido:
«Este sepulcro encierra
los que al cielo volaron por su tierra.»

También se hace eco la poesía de Viera del sentimiento filantrópico desarrollado por el prerromanticismo - especialmente en Quintana-, como se puede ver en el soneto dedicado «A la expedición de la vacuna», o en los temas filosófico-morales, como «La felicidad» (1792), «Las buenas costumbres y las leyes humanas» (tres cantos), de 1795, y el poema dedicado a «La educación». Ya comenzado el nuevo siglo sigue componiendo poemas de distinto tipo, como los retratos panegíricos, compuestos en octavas reales, que se conservan en el manuscrito titulado El nuevo / Can mayor / del firmamento español / en el reinado del Señor Don Carlos cuarto (1788-1808) ${ }^{9}$, dedicados a don Antonio Porlier, don Domingo y don Bernardo Iriarte, etc., hasta el

9 Los Ms. originales se encuentran en la biblioteca canaria de la Universidad de La Laguna. 
número de trece. El retrato dedicado al conocido escritor ilustrado lanzaroteño, su primo, don José Clavijo y Fajardo dice así:

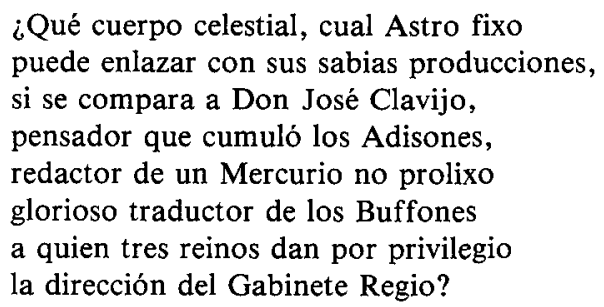

No hace falta explicar esta composición, pues Clavijo y Fajardo figura en todas las Historias de la Literatura, como personaje dramático y como escritor ilustrado y polemista, director del Mercurio y de $E l$ Pensador, traductor de Buffon y de comedias francesas y renovador del teatro español ${ }^{10}$.

Viera y Clavijo sigue alternando, en los últimos años de su vida, los temas de sus poesías entre lo patriótico, religioso y científico. Así del primero tenemos el tema heroico canario con su oda dedicada a la «Marcha del batallón de Gran Canaria» (1808) que iba a luchar contra las tropas de Napoleón en la península. (En ese batallón irían los que, corriendo el tiempo, serían el tío y el padre de don Benito Pérez Galdós.)

Hacia 1782, Viera, influido por Cavanilles, estudia Botánica, poco tiempo antes de emprender su viaje a Canarias para tomar posesión de su plaza de Arcediano de Fuerteventura. Alli pone en práctica sus conocimientos de química e historia natural, aplicados al estudio de las particularidades zoológicas, botánicas y mineralógicas que le ofrecen las islas. Nos interesa destacar ahora cómo fue clasificando y agrupando la flora canaria según el antiguo sistema sexual de Linneo. Fruto de estos trabajos serían su Diccionario de Historia Natural de las Islas Canarias (1799-1810) ${ }^{11}$, y el Catálogo de plantas indígenas de Canarias (1808) y el poema La boda de las Plantas (1804) ${ }^{12}$, que comienza declarando su objetivo:

Los desposorios de la amable Flora cantar en un vergel es mi deseo,

10 Véase Agustín Espinosa, Don José Clavijo y Fajardo, ed. Cabildo Insular Gran Canaria, 1970.

11 1. $^{\text {a }}$ ed., Museo Canario, Las Palmas, $1942 ; 2 .^{\mathrm{a}}$ ed., Manuel Alvar, Plan Cultural Mancomunidad de Cabildos de Las Palmas, 1982.

12 Ed. Colegic Farmacéuticos de Las Palmas, 1975, sobre ed. anotada y prologada por D. Juan Teixedor, Universidad de Barcelona, 1873. 
cuyo canto desarrolla, en cuarenta y siete octavas reales, según la estructura de los poemas épicos del siglo XVI y los cantos didácticos del siglo XVIII, todas las características de las distintas especies clasificadas según los órganos sexuales: monoicas, dioicas, hermafroditas, etc., con tal lujo de detalles que se hace digno de la mejor clasificación profesional (pues para ilustrar sus conferencias de botánica estaba destinado el poema), pero también de cierto regodeo erótico en torno el tema del himeneo vegetal en relación con el humano. Sienta desde la estrofa tercera lo que podrían ser las bases de una antropología vegetal:

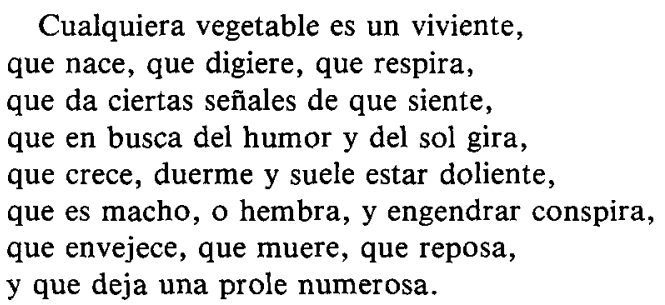

Al imperio del amor, motor de la reproducción de las especies animales, se someten también las vegetales, que pasan por todas las etapas -igual que el hombre- del desarrollo, hasta alcanzar la pubertad, época en que se consuma la unión sexual o matrimonial, como se expresa en la estrofa oncena:

A estas leyes de amor, que a los vivientes para su bien dictó Naturaleza, fieles los vegetales y obedientes, se rinden con pasión y con viveza: por eso, al ver que se hallan florecientes, señal de pubertad no sin presteza a su destino dando testimonio, procuran contraer el matrimonio.

En una perfecta alegoría Viera correlaciona, miembro a miembro, los elemenos de la metáfora continuada de los órganos sexuales de las plantas con los humanos, incluidas las circunstancias de la ceremonia matrimonial, no exenta de misterio y escondido deleite, como vemos en la estrofa trece:

No lo dudéis, la Flor es una boda; el cáliz es el tálamo y el lecho; los pétalos, lucidos y de moda, son las cortinas, que al capullo han hecho, y el gran misterio encubren; aula toda se perfuma de olores hasta el techo; y el néctar, que la abeja allí codicia, es el pan de la boda y la delicia.

Dentro de los poemas heroico-costumbristas se puede clasificar 
Las Cometas (1812), una de las últimas composiciones de Viera, donde parece querer combinar la oriental invención sutil y el experimento científico, resumir la fórmula horaciana, a la que siempre había permanecido fiel: «utile et dulce». Con su comienzo cerramos el ciclo vital y poético de nuestro poeta e historiador, que habrá que estudiar más profundamente para colocarlo en el lugar que le corresponde en el parnaso del neoclasicismo español:

Anda cometa bella toma de mi mano el vuelo y vete subiendo al cielo hasta parecer estrella, extiende como centella esa cola con que brillas y corriendo largas millas por los aires más ligeros asusta a los gallineros, y espanta a las aguilillas.

\section{INDICE DE OBRAS POETICAS ${ }^{13}$}

\section{TRADUCCIONES}

1. Henriada de Voltaire.

2. Los jardines (El arte de hermosear paisajes) por el Abate Delille.

3. Geórgicas (Algunas partes) de Virgilio.

4. El rizo de los cabellos robados de Pope.

* 5. El poema a la religión de Racine.

\section{ORIGINALES}

a) Poesía heroica.

1. Los Vasconautas (1757-1765). Ed. de J. M. Pérez Corrales, Seminario de Literatura Canaria, Universidad de La Laguna, 1983.

* 2. El Segundo Agatocles, Cortés de Nueva España.

3. Rendición de Granada.

b) Poesía didáctica-científica.

1. Los aires fijos (1779). Ed. Las Palmas, 1876.

2. Las bodas de las plantas (1804). Ed. Las Palmas, 1873.

* 3. Al globo aerostático.

* 4. Las cuatro partes del día.

* 5. Las cometas (1812).

6. Los meses (1779). Ed. Santa Cruz de Tenerife, 1849.

13 Se indican con asterisco los inéditos. 
c) Poesía filantrópica.

* 1. A la expedición de la vacuna.

* 2. El Herodes de las niñas, las viruelas.

3. Las buenas costumbres y las leyes humanas (1795).

4. La felicidad (1792).

5. La educación.

d) Poesía lírica-bucólica.

1. La fruta verde del Parnaso (Colección de poesias).

* 2. Oda a las parejas de Aranjuez (imitación de Horacio).

* 3. Egloga genetliaca (imitación de Virgilio).

* 4. Los sentimientos afectuosos (imitación de Blain de Saint-Mort).

5. Anacreónticas (Festín de las Vistillas).

* 6. La Mujer (oda anacreóntica).

7. El sentimiento (poema).

* 8. A una tórtola.

e) Poesía panegírica-histórica.

* 1. Epitafio del Vizconde de Buen Paso (1762).

2. Constelación canaria (13 ilustres canarios).

* 3. Al Marqués de Santa Cruz.

* 4. A la Marquesa de Santa Cruź.

* 5. A don Diego Nicolás Eduardo.

* 6. Al nacimiento de los infantes gemelos (1783).

* 7. A Mariano de Walestein (1781).

* 8. Al Escorial.

* 9. A las cuatro jornadas anuales de Carlos III.

10. Oda al General Gutiérrez (1797).

11. A la victoria sobre el Almirante Nelson (1805).

* 12. Epitafio del Almirante Nelson.

* 13. Marcha del batallón de Gran Canaria (1808).

* 14. A la elocución del Ilmo. Sr. Guillén.

* 15. A don Pedro Gutiérrez Bueno.

* 16. Al fallecimiento del Sr. Marqués de Santa Cruz.

* 17. Al Excmo. Sr. Obispo D. Manuel Verdugo.

* 18. A la caída de Godoy.

f) Poesía satírica.

* 1. Títulos de Comedias españolas adaptadas al carácter de cada dama y caballero de La Laguna.

* 2. Chulada burlesca a la intemperie de La Laguna (publicada en Antología de la poesía de La Laguna de S. de la Nuez, Sta. Cruz de Tenerife, 1983).

* 3. El romance de la nueva moda de la cabeza trasquilada.

* 4. De las modas, trajes y usos ridículos de los hombres.

* 5. Adán (quintilla).

* 6. Sátira a la nobleza de Boileau. 
g) Poesía religiosa.

* 1. Gozos a la Concepción de María.

* 2. Décimas glosadas a la fiesta de Teror.

* 3. A la festividad de San José.

* 4. A los Dolores de la Virgen.

* 5. Los responsorios de la Natividad y Epifanía.

* 6. Los quince misterios del rosario.

* 7. El rosario de las Musas. 